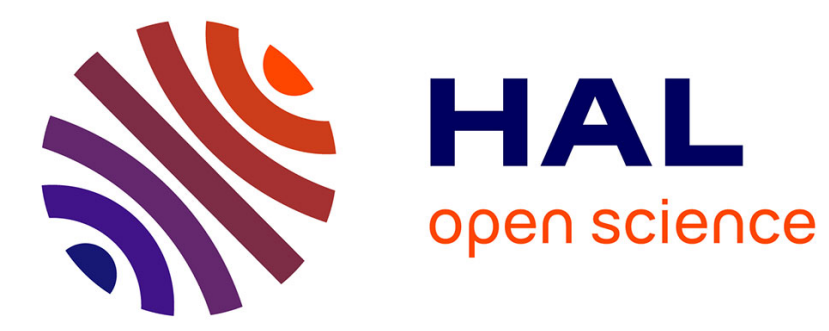

\title{
Gapping also needs vP-coordination: An argument from French NPI licensing
}

\author{
Anne Dagnac
}

\section{To cite this version:}

Anne Dagnac. Gapping also needs vP-coordination: An argument from French NPI licensing. Linguistic Review, 2016, Special Issue: Ellipsis: licensing, structure and identity, 33 (4), pp.503-530. 10.1515/tlr-2016-0014 . halshs-01588575

\section{HAL Id: halshs-01588575 https://shs.hal.science/halshs-01588575}

Submitted on 31 Dec 2017

HAL is a multi-disciplinary open access archive for the deposit and dissemination of scientific research documents, whether they are published or not. The documents may come from teaching and research institutions in France or abroad, or from public or private research centers.
L'archive ouverte pluridisciplinaire HAL, est destinée au dépôt et à la diffusion de documents scientifiques de niveau recherche, publiés ou non, émanant des établissements d'enseignement et de recherche français ou étrangers, des laboratoires publics ou privés. 


\title{
Anne Dagnac* \\ Gapping also needs vP-coordination: An argument from French NPI licensing
}

DOI 10.1515/tlr-2016-0014

\begin{abstract}
The analysis of gapping still leaves many questions open. At least three aspects remain controversial: whether it involves unpronounced structure, whether clausal or non-clausal constituents are conjoined, and whether all gapped sentences are must be analyzed uniformly. On the basis of French gapped constructions such as Marie n'est jamais allée à Rome ni Jean à Pékin 'Mary never went to Rome nor John to Beijing', the paper argues that gapping is not an homogeneous phenomenon. It first shows that in such gapped clauses involving ni, a strict Negative Polarity Item, a negation low inside the first TP can license the 'negative coordinator' ni, a fact that a TP-deletion analysis of gapping or a fragment coordination one can capture. Conversely, it shows that a vP-coordination analysis correctly predicts the properties of nigapped clauses. However, such an analysis cannot extend to gapped clauses conjoined by double ni : the second conjunct, this time, must be a full clause or a fragment.
\end{abstract}

Keywords: gapping, ellipsis, French, syntax, negative polarity item

$$
\begin{array}{r}
\text { "le presbytère n’a rien perdu de son charme, } \\
\text { ni le jardin de son éclat" } \\
\text { (G. Leroux, Le Parfum de la dame en noir) }
\end{array}
$$

\section{Introduction}

Besides the question whether gapping involves unpronounced structure (see among others Sag 1976. Johnson 1996; Hartmann 2000; Coppock 2001; Merchant 2004; Chaves 2005; Culicover and Jackendoff 2005; Toosarvandani 2013), the kind of constituents that are conjoined in gapped clauses is controversial, too. Gapping has been argued to involve either TP-coordination

*Corresponding author: Anne Dagnac, CLLE, Université de Toulouse, CNRS, UT2J, France, E-mail: dagnac@univ-tlse2.fr 
(a.o. Hartmann 2000; Kim 2006; Gengel 2009), vP-coordination (Coppock 2001; Johnson 1996, 2009; Toosarvandani 2013), or a fragment coordinated to the first TP (a.o. Culicover and Jackendoff 2005; Abeillé et al. 2011), while Repp (2009) and Centeno (2011) show respectively for German and Spanish that gapping is not a uniform phenomenon. This paper argues that the latter proposal holds for French, too, on the basis of gapped constructions involving the so-called 'negative coordinator' ni 'nor', as in Marie n'est jamais allée à Rome ni Jean à Pékin 'Mary never went to Rome nor John to Beijing'. The first section presents $n i$ as a strict Negative Polarity Item (de Swart 2001), which must be in the syntactic scope of a negation. The second section shows that under gapping even a negation inside the first TP can license $n i$, and argues that neither a TP coordination view of gapping nor a fragment one accounts for these facts. The third section shows that, conversely, a vP-coordination analysis correctly predicts the properties of ni-gapped clauses. The last section, however, proposes that gapped clauses conjoined by simple $n i$ and by double $n i$ involve conjuncts of different sizes.

\section{The French negative coordinator ni}

French ni can appear in two guises: a simple coordination, as in (1), which I will focus on, or a double one, reminiscent of English neither... nor, as in (2). ${ }^{1}$

(1) Je n’ai pas parlé $\int_{P P}$ à Paul] ni $\int_{P P}$ à Pierre]. I SM have not talked to Paul nor to Peter 'I didn't talk to Paul nor to Peter'

(2) Je n'ai parlé ni $\left[_{P P}\right.$ à Paul] ni ${ }_{P P}$ à Pierre]. I SM have talked neither to Paul nor to Peter 'I talked neither to Paul nor to Peter'

Just as other coordinators, ni can conjoin various kinds of heads, phrases, cf.(2), (3), or, most importantly here, clauses, cf. (4), (5).

1 In the text or the glosses, the following abbreviations are used: ConD: conditional, DAT: dative, ECM: exceptional case marking, FUT: future, NEG: negation, NPI: negative polarity item, PART: partitive, REFL: reflexive, SM: scope marker. For the latter, see note 3. 
(3) vP-coordination

Je n' ai jamais [vP vu Paul] ni [vP parlé à Pierre].

I SM have never seen Paul nor talked to Peter

'I have never seen John nor talked to Peter'

(4) Clausal coordination (tensed verb)

Jamais Tim ne serait allé à Paris ni Léa ne serait allée

Never Tim sm be.cond gone to Paris nor Lea SM be.cond gone

à Rome.

to Rome

'Never Tim would have gone to Paris nor would Lea have stayed in Rome'

(5) Clausal coordination (ECM construction)

Jamais les envoyés du roi Jacques n' avaient $v u$

Never the messengers of.the king Jacques sm had seen

autant de rivières se jeter les unes dans les autres

so many rivers REFL throw the ones into the other

ni autant de gorges et de vallées s'entrelacer.

nor so many canyons and valleys REFL.intertwine

'Never had King Jacques' messengers seen as many rivers flow into each other nor as many canyons and valleys intertwine.' (J Lanzmann, La Horde d'or, p. 346)

Both simple and double ni are classically called 'negative coordinating conjunctions'. However, de Swart (2001) and Mouret (2007) convincingly argue that simple ni is not a negation but a strong NPI. In the next sections, I sum up their arguments, and then show that ni is subject to a syntactic licensing constraint.

\section{$2.1 \mathrm{Ni}$ is a NPI}

De Swart (2001) and Mouret (2007) conclude from semantic and distributional arguments that in present French ${ }^{2}$ simple $n i$ is a strong/strict NPI: ni can only appear in downward entailing non-additive contexts; it must be within the

2 Previous stages of the language allowed for weaker contexts, including interrogatives, rarely, etc, as detailed by De Swart (2001). This usage survives marginally in literary formal style with an archaïc flavor. 
semantic scope of a negation present in the first conjunct or of the averidical preposition sans ('without'). De Swart further argues that ni can be seen in logical terms as a polar version of ou ('or') - a or in the scope of negation; $A$ ni $B$ then corresponds to $\neg(A \vee B)$, logically equivalent to $(\neg A) \wedge(\neg B)$. (6a) shows that $n i$ is ruled out when no negation is present, $(6 \mathrm{~b})$ that it is ruled out in non-additive contexts. These cases contrast sharply with (7), where a negative word precedes ni.

(6) a. ${ }^{*} I l$ (n') a parlé à Marie ni à Pierre. [no negation]

He sm Has talked to Mary nor to Peter

'He talked to Mary nor to Peter'

b. ${ }^{*}$ Il voit rarement Paul ni Marie. [not non-additive]

He sees rarely Paul nor Mary

'He rarely sees Paul nor Mary'

(7) a. Il n’ a pas/jamais parlé à Marie ni à Pierre.

He sm has not/never talked to Mary nor to Peter

'He did not/never talk to Mary nor to Peter'

b. Personne n'a parlé à Marie ni à Pierre.

Nobody sm has talked to Mary nor to Peter

'Nobody talked to Mary nor Peter'

c. Il est venu sans Marie ni Pierre.

He has come without Mary nor Peter

'He came without Mary nor Peter'

In this respect, ni clearly differs from English nor, which can occur in a sentence that contains no previous negation (Huddleston and Pullum 2002), and may be analyzed as $\wedge \neg$ (Wurmbrand 2008) - (9), the French equivalent of (8), is completely out:

(8) a. He was one of those people who can't relax. Nor did he have many friends.

b. The hotel had good views and a private beach; nor were these its only attractions.

(9) a. C'était un de ces hommes qui ne savent pas se détendre. It was one of these men who SM know not RefL.relax ${ }^{*} \mathrm{Ni}$ il (n') avait beaucoup d' amis.

Nor he (sm) had a lot of friends

b. L'hôtel avait une vue splendide et une plage privée The hotel had a view splendid and a beach private ${ }^{*} \mathrm{Ni}$ ce (n') étai(en)t ses seuls attraits. Nor this (sm) was(were) its only attractions 
Neither de Swart nor Mouret, however, examine in which conditions this semantic scope can actually license ni. In the next section, I claim that the licensing condition on ni must be expressed in syntactic terms.

\title{
2.2 Ni must be in the syntactic scope of a negation
}

The classical view for NPI licensing is that semantic scope has a syntactic counterpart, which is traditionally expressed by the fact that NPIs must be c-commanded by their licensor. This view has been challenged, most radically by Hoeksema (2000), who argues that NPI licensing does not actually require syntactic ("surface") c-command, and can rely on purely semantic factors ("LFc-command"). While Hoeksema's proposal may be correct for weaker NPIs, it cannot apply to the licensing of the French strong NPI ni, for which the descriptive generalization in (11) applies, and this proves crucial for an analysis of gapped constructions in $n i$.

(11) Ni must be in the syntactic scope of a negation in overt syntax.

Some terminological precision is necessary as to what counts as a negation in French. I consider that it subsumes the negative marker pas and 'negative expressions' (Godard 2004) such as personne 'nobody', rien 'nothing', aucun, nul 'no', jamais, 'never', nulle part 'nowhere', plus 'no longer' and PPs containing them, as well as the preposition sans 'without': these negative words can indeed all act as constituent negation, cf. (12), and induce a double negation reading when they co-occur in a suitable pragmatic context, cf. (13) ${ }^{3}$;

3 I abstract here from the preverbal clitic ne, which is no longer semantically negative in French, and is classically analyzed as a scope marker, since in (ia), it marks that the negation born by personne scopes over the infinitive clause, in (ib), that it scopes over the main clause.
a. Paul accepte [de ne voir personne].
Paul agrees $\mathrm{C}^{\circ} \overline{\mathrm{SM}}$ see nobody
'Paul agrees to not seeing anybody'
b. Paul $\underline{n}$ ' accepte [de voir personne].
Paul SM agrees $\mathrm{C}^{\circ}$ see nobody
'Paul does not agree to see anybody'

\begin{abstract}
Alternatively, one can consider that ne is an NPI (Zeijlstra 2010), or a negative agreement morpheme on $\mathrm{V}$, signaling that the TP hosting it is negative. I will traditionally gloss it as SM for 'scope marker'.
\end{abstract}


(12) C'était une femme dure, pas jolie, jamais contente, aimable It was a woman harsh, not pretty, never happy, kind pour personne, sans chaleur. to nobody, without warmth 'It was a harsh woman, not pretty, never happy, kind to nobody'

(13) Il ne peut pas être misanthrope à ce point: He sM can not be misanthropic to this point: PERSONNE $n$ ' aime personne! nobody sm likes nobody 'He can’t possibly be such a misanthropist: nobody likes nobody!'

We can now turn back to the claim in (11), which accounts for otherwise mysterious data as to the behavior of ni: while (14), (15a) and (16b) are perfect, (15b) and (16a) are not, though they contain a negation:

(14) Je n' ai pas/jamais/plus parlé à Jean ni à Pierre. I SM have not/never/no longer talked to John nor to Peter 'I have not/never/no longer talked to John nor to Peter'

(15) a. Personne n'a parlé à Jean ni à Pierre. Nobody SM has talked to John nor to Peter 'Nobody talked to John nor to Peter'

b. ${ }^{*}$ À Jean ni à Pierre, personne ne leur $/ n$ ' a parlé. To John nor to Peter nobody sM them.DAT / SM has talked 'To John nor to Peter, nobody talked (to them)'

(16a) ${ }^{*} J e a n$ ni Pierre ne $m$ ' ont jamais parlé. John nor Peter SM me.DAT have never talked 'John nor Peter did never talked to me'

(16b) Jamais Jean ni Pierre ne m' ont parlé. Never John nor Peter SM me.DAT have talked 'Never did John nor Peter talk to me'

A reason for this may be that the negation must linearly precede ni. However, when it comes to clausal coordination, precedence proves not to be enough: in (17) and (18), the negation precedes ni, and the sentences are still ruled out:

(17) ${ }^{*} J e a n$ ne votera pas/jamais pour Tim ni Marie ne s'abstiendra. John sm vote.Fut not/never for Tim nor Mary sm abstain.Fut 'John will not/never vote for Tim nor will Mary abstain' 
(18) `Jim n' ira pour rien au monde à Madrid Jim SM go.fut for nothing in.the world to Madrid ni Marie ne restera à Rome nor Mary sm stay.fut in Rome 'Jim won't go to Madrid for any reason nor will Mary stay in Rome'

However, when the negation stands in the left periphery, in a position higher than both conjoined TPs, clausal coordination by ni is ruled in back as $\left(17^{\prime}-18^{\prime}\right)$, the counterparts of (17-18), show:

(17') Jamais Jean ne votera pour Tim ni Marie ne s'abstiendra. Never John SM vote.FuT for Tim nor Mary SM abstain.FuT 'Never will John vote for Tim nor will Mary abstain'

Pour rien au monde Jim n' ira à Madrid
For nothing in.the world Jim SM go.Fut to Madrid
ni Marie ne restera à Rome.
nor Mary sM stay.FuT in Rome

'For no reason will Jim go to Madrid nor will Mary stay in Rome'

The descriptive generalization is then as follows: as far as licensing $n i$ is concerned, a negation inside TP scopes over vP; a negation in the left periphery scopes over TP. Zeijlstra's (2010) analysis of French negation offers a way to formalize it. In his view, negative expressions bear a [uNeg] feature, checked by an abstract [iNeg] syntactic operator, Op $\neg$. Let's assume classically that pas stands in a NegP between T and vP - cf. Laka's (1990) lower $\sum$ P, or Zanuttini's (2001) NegP2, and that it also hosts $\mathrm{Op}_{\neg}$ checking negative expressions. The generalization in (11) can then be reformulated as (19), where negation encompasses pas, negative expressions and $\mathrm{Op}_{\urcorner^{4}}$ :

4 C-command by a semantically negative item seems to be the right formulation for simple negative expressions, such as jamais, nulle part, rien, etc. The picture is a bit more complex with PPs hosting a negative expression: in this case, the PP and not the negation itself must ccommand $n i$, and then counts as negative. The proper analysis of this fact exceeds the size of this paper (see for instance discussion in Kayne 1994; Hoeksema 2000): the important point here is that precedence is still not enough in this case, and the asymmetries pointed to in (1417) hold, as (18) shows: the negative PP must be in a surface position from which it can scope over the conjoined full TPs to licence ni. 
(19) Ni must be c-commanded by a negation in overt syntax.

In (14), ni is c-commanded by pas or $\mathrm{Op}_{\neg}$, in (15) by the negative subject. ${ }^{5}$ In (15b), left-dislocating or fronting the indirect object above personne, where ni is no longer c-commanded by any part of the negation, makes the sentence bad. In (16a), neither $O p_{\neg}$ nor jamais c-commands ni, and the sentence is ruled out, ${ }^{6}$ while in (16b), having jamais stand in the left periphery of the clause makes it good again $^{7}$ : following Benincà and Poletto (2004), we assume this position to be

5 Note that $n i$ would also be licensed between the negative subject and $O p_{\neg}$ as in (i):(i) Personne, à Paris ni à Rome, ne leur a $\mathrm{Op}_{\urcorner}$parlé.'Nobody, in Paris nor in Rome, talked to them'.

6 In literary French, one can find subjects conjoined by ni, as in (i). However, they are generally found either in coordination with a N-word, or in contexts where ne can express negation by itself, remains of a former stage of the language:

(i) Les donataires, les légataires, ni les créanciers du défunt ne pourront demander cette réduction ni en profiter. (Jean Jaurès, Études socialistes, 1901, p. 196-197)

Lit. 'The donees, the legatees nor the creditors of the deceased NEG will be entitled to ask this reduction nor benefit from it'

The very few other exceptions found in Frantext sound definitely odd and literary, to me and to all the persons I submitted the sentence to. In (ii), ne also acts as the sole negation:

(ii) Les pauvres, les travailleurs ni leurs quartiers n’intéressent Aimée. (J. P. Manchette, Fatale, 1977, p. 24)

Lit. 'The poor, the workers nor their neighborhoods interest Aimée.'

I then consider they are all remnants of a former stage of the language, where ni was a weak NPI, that some speakers (including one reviewer) have retained.

7 One reviewer suggests that these facts should correlate with different semantic scope of the negation over universal quantifiers. To the extent that such inverse scope is available in French with negative expressions (a negative subject entering negative concord, as in (i), sounds far much natural), this seems to be born out. When speakers accept the marginal (ii), they do it with the expected reading, while (iii), though marginally ambiguous, has the reverse one:

(i) Aucun collègue ne m'a jamais parlé de cet article

No colleague sm to.me has ever talked of this paper

'No colleague has ever mentioned this paper to me'

Only available meaning: 'No colleague is such that he ever mentioned this paper to me'

(ii) ?Tous les collègues ne m'ont jamais parlé de cet article

All the colleagues sm to.me have ever talked of this paper

'All the colleagues never mentioned this paper to me'

"Every colleague is such that he never mentioned the paper"

Excluded: "it was never the case that all colleagues mentioned the paper" 
within the CP field, though our analysis would not crucially change if the negative adverbials were adjoined to TP. I will neutrally label this functional position FP. ${ }^{8}$

Importantly, the same contrast holds for TP-coordination: when the negative expression is embedded in the first TP conjunct, as in (17a) and (18a), the sentence is ruled out, since, whatever view of coordination one adopts, it does not c-command ni. This is shown in (20) which sketches in (A) the classical analysis of TP conjuncts, and in (B), an alternative representation along the lines of Munn (1992) ${ }^{9}$ :

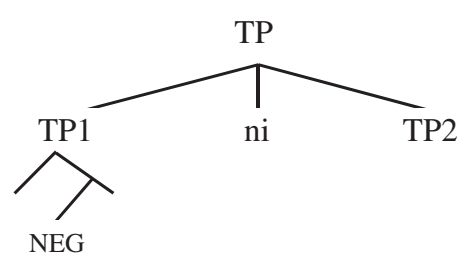

(A)

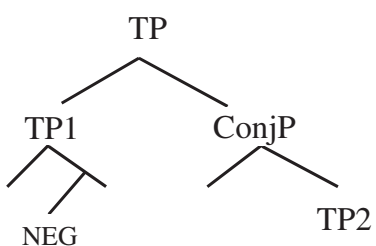

(B)

However, when the negative expression is allowed to stand in the left-periphery of TP as in (17b) and (18b), it licenses ni, since it can scope over the conjoined TPs, as (21) shows:

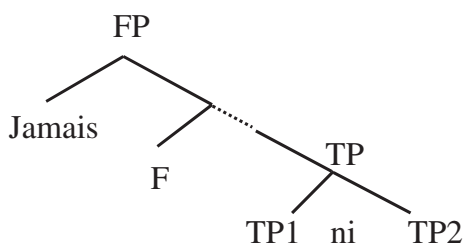

(iii) Jamais tous les collègues ne m'ont parlé de cet article

Never all the colleagues sm to.me have talked of this paper

'Never did all colleagues mention this paper to me'

Prefered: "it was never the case that all colleagues mentioned this paper'

Strongly disliked "Never did any colleague mention this paper".

8 Or in a higher $\sum$ P position hosting Emphatic Negation (Laka 1990): judgements on the possibility to front more than one negative word are messy, and this point needs further investigation. The crucial point here is that the projection is higher than TP. It is also irrelevant here whether they are merged or moved there, though this may have implications for the structure of coordination: if they are moved there, it must be via ATB-movement in a structure of type (A) below, not in a structure of type (B).

9 For arguments, especially in French, against Kayne's (1994) proposal that the conjunction heads a ConjP whose specifier is TP1, see Borsley (2005). 
The same holds for clauses selected by the negative preposition sans 'without': it always dominates the CPs it introduces, cf. (22), and then can license clausal ni. (23) is therefore grammatical.

(22)

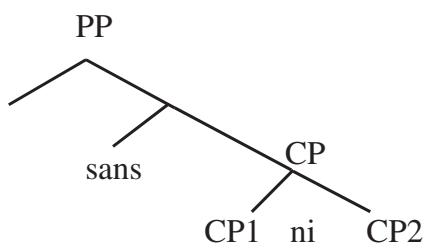

(23) Cela s'est réglé sans que Paul aille à Paris

This refl.is solved without that Paul go.suBj to Paris

ni que Marie aille à Rome.

nor that Mary go.subj to Rome

'This was solved without Paul going to Paris nor Mary going to Rome'

All these contrasts clearly argue that in order for $n i$ to be licensed, syntax and semantics must converge: its trigger must stand in a higher scopal position, before LF. In the next section, we turn to the consequences of this syntactic constraint on the analysis of ni-gapped sentences.

\section{$3 \mathrm{Ni}$ and gapping: Consequences of a licensing asymmetry}

$\mathrm{Ni}$ can also occur in gapped conjuncts, as in (24):

(24) Jamais Angiolina n' a été aussi amoureuse de Never Angiolina sm has been si in love of moi ni moi d'elle. me nor me of her

'Never has Angiolina been so much in love with me nor me with her' (G. Matzneff, Ivre de vin perdu, 1981, p. 242)

In such cases, $n i$ is correctly scoped over by the preposed N-word jamais, and (24) is predicted to be good, whatever the right analysis of gapping. The same holds for the gapped equivalents of $\left(17^{\prime}-18^{\prime}\right)$ in $(25-26)$. Whether the second conjunct is a TP, a vP, or a fragment, $n i$ is indeed under the scope of the negative 
expression above the first TP, and whether the missing verb in the second conjunct is ATB-moved à la Johnson, unpronounced or lacks any syntactic reflex, is irrelevant in this respect.

(25) Jamais Jean ne votera pour Tim ni Marie pour Jo. Never John SM vote.Fut for Tim nor Mary for Jo

'Never will John vote for Tim or Mary for Jo'

(26) Pour rien au monde Jim n' ira à

For nothing in.the world Jim SM go.fuT to

Madrid ni Marie à Rome.

Madrid nor Mary in Rome

'For no reason will Jim go to Madrid or Mary to Rome'

However, gapped counterparts of the ungrammatical (17a-17b) also prove to be grammatical, as (27-28) show.

(27) Jean ne votera pas/jamais pour Tim ni Marie pour Jo. John sM vote.fuT not/never for Tim nor Mary for Jo 'John will not/never vote for Tim nor Mary for Jo'

(28) Jim n' ira pour rien au monde à Madrid Jim SM go.fuT for nothing in.the world to Madrid ni Marie à Rome.

nor Mary in Rome

'Jim won't go to Madrid for any reason nor will Mary to Rome'

This contrast between an ungrammatical full conjunct (29a) and a grammatical gapped one obtains whether an auxiliary (29b), a full verb (29c) or a larger chunck (29d) is gapped. The data in (29) argue for a common analysis of gapping in sentences such as (29b-d), so I won't distinguish these cases.

(29) Bunk n' a pas trouvé de suspect dans le quartier, Bunk sM has not found of suspect in the neighborhood 'Bunk has not found any suspect in the neighborhood'

a. ${ }^{*}$ ni Kima n'a trouvé d'indices dans l'immeuble. nor Kima sM has found of clues in the building 'nor has Kima found any clue in the building'

b. ni Kima trouvé d'indices dans l'immeuble.

nor Kima found of clues in the flat 'nor Kima found any clue in the building' 
c. ni Kima d'indices dans l'immeuble.

nor Kima of clues in the flat

'nor Kima any clue in the building'

d. ni Kima dans l'immeuble.

nor Kima in the flat

'nor Kima [any suspect] in the flat

Accounts of gapping must then explain why the gapped structure is grammatical in contexts where a full clause would be ruled out for lack of a suitable licensor for ni. We turn now to two main accounts of gapping, the 'TP-deletion analysis' and the 'fragment analysis', and show that they fail to account for these data.

\subsection{TP-deletion cannot account for the data}

Clearly, these cases cannot be accounted for by a TP-deletion analysis of gapping. Under this view, the full and gapped clauses would share the same agrammatical syntactic structure before $\mathrm{PF},{ }^{10}$ part of which would then get unpronounced. For instance, the pre-PF structure of the gapped clause in (31) would be similar to the ungrammatical (30), the only difference being that the bracketed items in (31) would not be pronounced.

(30) `Jean ne votera jamais pour Tim ni Marie ne votera pour Jo. John SM vote.fuT never for Tim nor Mary sm vote for Jo 'John will never vote for Tim nor will Mary vote for Jo'

(31) Jean ne votera jamais pour Tim ni Marie [ne votera] pour Jo. John sm vote.Fut never for Tim nor Mary sm vote for Jo 'John will not/never vote for Tim nor Mary for Jo'

This analysis predicts that ni would fail to be licensed in overt syntax, and the gapped sentence should be ruled out for the same reason the full one is. Since the offending configuration (the non-c-commanding negation) lies completely outside of the unpronounced structure, as shown in (32), none of the usual repair

10 Movement of the remnants to a Topic/Focus or another leftward position inside the second conjunct does not bear on the issue at stake: we omit it for simplicity. 
devices invoked to account for a grammaticality mismatch between full and elliptical structures (see e. g. Sag 1976; Merchant 2008), such as the deletion of an illicit trace, can be appealed to in order to account for the grammaticality of (31) once it has been processed at PF.

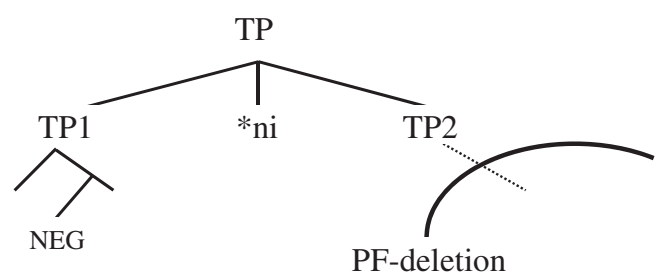

Since there is no reason why the non-pronunciation of the TP should affect in any way the licensing of $n i$, which stands outside the potential unpronounced structure, one must conclude that these gapped sentences cannot proceed from clausal coordination followed by a PF-deletion process.

\subsection{Fragment approaches}

Does a fragment approach such as Abeillé et al.'s (2011) fare better in this case? In this view, the gapped constituent is conjoined to TP, too, but it does not have the inner syntax of a clause, as sketched in (33): this special constituent, called $\mathrm{XP}$ in the tree, is a headless fragment that gets its clausal meaning through a special semantic process that maps it to the semantics of the clausal antecedent (see e. g. Dalrymple et al. 1991).

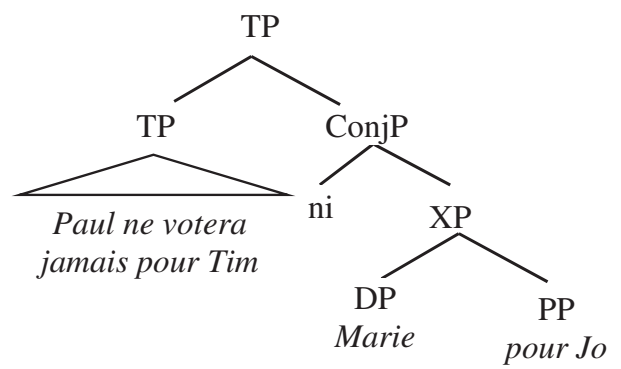

However, ni is still not c-commanded by the negation which is buried in the first clause, and it remains mysterious how the semantic process that maps the gapped construction to a clausal meaning would loosen the syntactic constraint on the licensing of an external ni. 
If, as Abeille (2005) argues for stripping, the fragment is adjoined to the first clause, it must be somewhere in the scope of negation, so at least below the projection in which $\mathrm{Op}_{\neg}$ stands - for instance, to vP. But this alternative would run into another problem: the sentence in (34) could not proceed from ATB extraction of the WH-phrase, since the WH-P should move simultaneously from the main clause and its adjunct.

(34) $A$ qui i est-ce que Paul n' a pas offert de vin $t_{i}$ To whom PART that Paul SM has not offered of wine $t_{i}$ ni Jim de foie gras $t_{i}$ ? nor Jim of foie gras $t_{i}$ ?

'Whom didn't Paul offer wine nor Jim foie gras?'

Conversely, asymmetric extraction from the first conjunct should be possible, contrary to facts, cf. the ungrammaticality of (35):

${ }^{*}$ qui $i_{i}$ est-ce que Paul n' a pas offert de vin $t_{i}$
To whom part that Paul SM has not offered of wine $t_{i}$
ni Jim de foie gras à ses parents?
nor Jim of foie gras to his parents
'Whom didn't Paul offer wine nor Jim foie gras to his parents?'

In their current shape, neither a PF-deletion nor a fragment approach ${ }^{11}$ seems able to predict the grammaticality of gapped clauses conjoined by ni: both

11 As a reviewer underlines, ni can head a fragment answer in the absence of any syntactic licensor, cf. (i). I consider these data fall under the ambit of an account of fragment answers, not of ni or gapping.

(i) Qui est-ce qui va semer ce blé? dit la petite poule rouge.

'Who is going to seed this wheat? said the little red chicken.

- Pas moi, dit le dindon.

'Not me', said the turkey.

- Ni moi,dit le canard.

'Nor me, said the duck'

However, approaches that view gapping as an instance of fragment coordination can capitalize on the fact that both elliptical contexts escape syntactic scopal constraints. Since the asymmetries I presented here affect clausal and non-clausal conjuncts alike, though, it cannot stem from the non-clausal nature of the fragment per se. Even for these analyzes, why syntactic constraints on the licensing of $n i$ are loosened then remains to be explained. 
require a stipulation that the licensing conditions on $n i$ should be somehow loosened in the elliptical structure. In the next section, I show that an analysis based on a smaller coordination makes the right predictions.

\section{$4 \mathrm{Ni}$ and vP-coordination analyses}

Gapping has been proposed to involve vP- rather than TP/CP-coordination (see in particular Johnson 1996, 2009; Coppock 2001): one aim of these proposals was to account for sentences such as (36), where the negation scopes over the conjunction and does not distribute over the conjuncts - which the ni cases echo under a different guise:

(36) Ward cannot eat caviar and Sue beans.

\# 'Ward cannot eat caviar and Sue cannot eat beans'

In Johnson's proposal, the vPs Ward eat caviar and Sue eat beans are conjoined below T; the verbs ATB-move to a higher Pred projection, while the first subject asymmetrically moves to spec, TP. Hence, the only deletion that occurs is deletion of the lower copies of moved items. Coppock (2001) and Toosarvandani (2013), while following Johnson in considering low coordination is required for (some cases of) gapping, argue that VP-ellipsis, rather than movement, is responsible for the gap. ${ }^{12}$ I will concentrate on Johnson's analysis, and show that low coordination directly accounts for the properties of French nigapped sentences.

\subsection{Ni and low coordination: The general case}

Along Johnson's lines, the ni-gapped sentence in (37) has the structure in (38):

(37) Paul nen' est pas/jamais allé à Paris ni Marie à Rome Paul SM is not/never gone to Paris nor Mary to Rome 'Paul has never gone to Paris nor Mary to Rome'

12 Since French rules out VP-ellipsis, the latter proposal would additionally have to explain why it licenses it just in this case. 
(38)
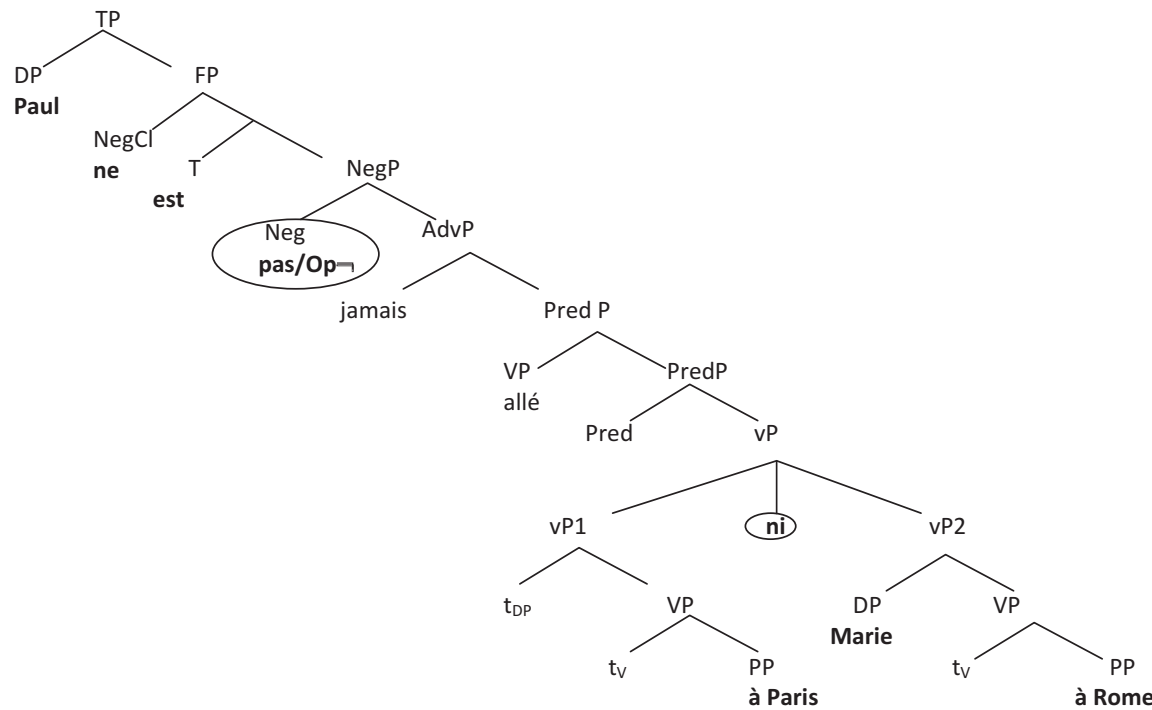

In this configuration, $n i$ is c-commanded by $\mathrm{pas}_{\mathrm{O}} \mathrm{O} \mathrm{p}_{\neg}$, which entails the possibility of $n i$ to be syntactically licensed in (37). ${ }^{13}$

Viewing ni-gapped sentences as proceeding from vP- rather than TPcoordination is compatible with the fact that though ni can conjoin clauses, it seems unable to conjoin bare TPs, while it conjoins easily CPs with an overt $\mathrm{C}^{\circ}$

13 A problem sometimes put forward against Johnson's proposal is that gapping allows WH-P remnants:

(i) Which books do you want to check out now, and which $\Delta$ next week? (Hankamer and Depiante 2005:15, quoted by Toosarvandani 2013)

The grammaticality of such constructions with French ni-gapped sentences seems very dubious to me:

(ii) ${ }^{*}$ Où n'est-il pas parti en décembre ni où en janvier?

'Where didn't he go in December nor where in January?'

This may support both the suggestion made by Toosarvandani (2013) that sentences like (i) do not involve low coordination, and mine that ni-gapped sentences do involve low coordination. 
or clauses with an extended left-periphery that can host a fronted negative expression. This is made clear when $n i$ is in the syntactic scope of sans, as the contrasts in (39) show:

a. On l'a fait sans que Paul pleure ni que Marie We it.have done without that Paul weep.subj nor that Mary s'inquiète. worry.suBJ

b. *On l'a fait sans que Paul pleure ni Marie We it.have done without that Paul weep.subj nor Mary s'inquiète.

worry.suBJ

'We did it without Paul weeping or Mary getting worried'

c. On l'a fait sans que jamais Paul ne pleure

We it.have done without that never Paul SM weep.suBj

ni Marie ne s'inquiète.

nor Mary sM worry.suBj

'We did it without Paul ever weeping or Mary getting worried'

A low coordination analysis is also in line with the most productive patterns of $n i$-coordination. Clausal-coordination by ni, though grammatical as long as a negative expression c-commands ni, is infrequent in French, while both nigapped sentences and vPs conjoined by ni are natural and relatively frequent. For instance, both ni-gapped conjuncts and ni-conjoined vPs like (40) can be found in the 500 texts written after 1965 hosted by Frantext, the national written corpus, which contain no occurrence of ni conjoining two main clauses.

(40) Il n' avait pas fait son devoir d'anglais, He sm had not done his exercice of English

ni préparé les interrogations écrites.

nor prepared the assignements written

'He hadn't done his English exercice, nor prepared the written assignments' (G. Pérec, Je suis né, p. 17)

More crucially, such an analysis also accounts for the availability of wide scope items in ni-gapped structures, while they are impossible in full ones, as the contrasts in (41-42) shows: 
(41) a. ${ }^{*}$ Ici, jamais chaque enfant ${ }_{i} n$ ' aura un violoncelle ni Here, never each kid sm have.Fut a cello nor ses parents $_{i}$ n' auront les moyens de lui $i_{i}$ en louer un. his parents sm have.Fut the money of to.him PART rent one 'Here, never will each child own a cello, nor will his parents have enough money to rent one for him'

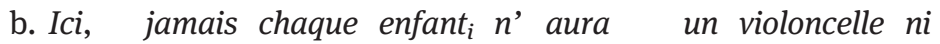
Here, never each kid sm have.Fut a cello nor ses parents $s_{i}$ les moyens de lui i en louer un. his parents the money of to.him PART rent one 'Here, never will each child own a cello, nor his parents enough money to rent one for him'

(42) a. ${ }^{*} I c i$, jamais aucun enfant ${ }_{i}$ n' a de portable ni son père ${ }_{i}$ Here never no child SM has of mobile nor his father ne conduit de BMW.

SM drives of BMW

'Here, never does any child have a mobile nor does his father drive a BMW'

b. Ici, (jamais) aucun enfant ${ }_{i} n^{\prime}$ a de portable ni son père ${ }_{i}$ Here (never) no child sM has of mobile nor his father de $B M W$.

of BMW

'Here, no child (ever) has a mobile nor his father a BMW'

In (41/42a), two clauses are conjoined by $n i$, and jamais scopes over $n i$ which is then correctly licensed. However, the subject of the first TP, chaque/aucun enfant, cannot scope over ses parents/son perre, ruling the sentence out. The same should be true of (41/42b) if they involved clausal coordination, too, contrary to facts. If they involve vP coordination, on the other hand, chaque/ aucun enfant can scope over ses parents/son père and the sentences are rightly predicted to be good.

\subsection{Gerunds and infinitives}

In this section, I focus on untensed clauses with a DP subject, whether the latter has special case properties, as in gerunds and ECM constructions, or is raised, 
as is the case after modal verbs in French. I show that a vP-coordination analysis is also compatible with the behavior of ni-gapped clauses in these contexts.

\subsubsection{Gerunds}

The asymmetry between an ungrammatical full conjunct and a grammatical gapped one also holds for gerund clauses with DP subjects.

(43) a. *Anne $n$ ' ayant plus d'argent ni Jim n' ayant de temps, Ann SM having no more of money nor Jim SM having of time ils ont annulé leur voyage.

they have cancelled their trip

'As Ann had no more money nor did Jim have any more time, they cancelled their trip'

b. Anne n' ayant plus d'argent ni Jim de temps, Ann sM having no more of money nor Jim of time ils ont annulé leur voyage.

they have cancelled their trip

'As Ann had no money left nor Jim time, they cancelled their trip'

This is predicted by our proposal since, apart for the special properties of their subjects, they share the structure of tensed clauses (cf. Pollock 1989: 408).

\subsubsection{Infinitives selected by modal verbs}

Infinitives selected by modal verbs can be conjoined by ni, as shown in (44), and the second conjunct can be gapped, cf. (45):

(44) Paul ne peut pas aller à Rome ni Marie quitter Madrid. Paul sm can not go to Rome nor Mary leave Madrid 'Paul can't go to Rome nor Mary leave Madrid'

(45) Paul ne peut pas aller à Rome ni Marie à Madrid. Paul SM can not go to Rome nor Mary to Madrid 'Paul can't go to Rome nor Mary to Madrid' 
Whatever the exact analysis of such structures, ${ }^{14}$ they are predicted to be good in our analysis, whether full or gapped, since ni is c-commanded by the negation in the main clause. ${ }^{15}$

14 Note that such constructions can be viewed either as a clausal coordination of the infinitive arguments of the modal, as in (i), or as involving a gapped modal in the second conjunct. In the latter case $n i$ would have to be c-commanded by the negation on the first modal, so, in our view, it would imply coordination of the two vPs headed by peut, as in (ii):

(i) Paul ne peut pas [TP/CP $\left(t_{\text {Paul }}\right.$ aller à Rome) ni (Marie quitter Madrid)]

Paul can't t $t_{\text {Paul }}$ go to Rome nor Mary leave Madrid

(ii) ([ ${ }_{T P}$ Paul ne peut pas $\left(_{v P}\left[_{v P 1} t_{\text {Paul }} t_{\text {peux }}\left({ }_{T P i n f} t_{\text {Paul }} T^{\circ}{ }_{\text {inf }}\left({ }_{v P} t_{\text {Paul }}\right.\right.\right.\right.$ aller à Rome $\left.\left.)\right)\right] n i\left[_{v P 2} t_{\text {peux }}\left(T_{\text {PPinf }}\right.\right.$ Marie $T^{o}{ }_{\text {inf }}\left({ }_{v P} t_{\text {Marie }}\right.$ rester à Madrid) $\left.\left.\left.)\right]\right)\right]$

In both cases the subject of the first conjunct must move to the specifier of the main TP. For French, the right structure is, as far as I can see, undecidable.

15 What is not predicted is the behavior of ni when the first conjoined infinitive hosts a negation. Though judgements are messy, both full and gapped infinitives seem indeed able to be conjoined by $n i$, as (i) and (ii) show respectively for epistemic and deontic readings of the modals.

(i) Jim pourrait ne pas aller à Rome.

Jim could SM not go to Rome

'Jim could NOT go to Rome'

a. ?/\% ni Marie rester à Madrid.

nor Mary stay in Madrid

'nor Mary stay in Paris'

b. ni Marie à Madrid.

nor Mary in Madrid

'nor Mary in Madrid'

(ii) Désormais, Jim peut ne plus jamais faire de maths

From now on Jim can sM no longer ever do of maths

'From now on, Jim can do maths no longer

a. ?/\% ni Marie lire de livres.

nor Mary read of books

nor Mary read books'

b. ni Marie de sport.

nor Mary of sports

nor Mary sports'

If full TPs are conjoined in (ia), and (iia), ni should fail to be licensed, since it is not ccommanded by the negation inside the first infinitive: for speakers that accept the sentence, only the infinitive vPs may be conjoined. The difference with ECM negated infinitives may also suggest that this behavior is linked either to the exact structure of raising verbs complements, or to the interferences between modality and negation. 


\subsubsection{Gapping and ECM infinitives}

Infinitives conjoined by ni can also be found after ECM negated verbs, in their full (46) and gapped (47) versions, unsurprisingly since the negation in the main clause is always in a position to license ni:

(46) Il n’a pas vu Jim parler à Léa ni Jean l'embrasser. He sM has not seen Jim talk to Lea nor John her kiss 'He didn't see Luc talk to Lea nor John kiss her'

(47) Il n’a pas vu Luc parler à Léa ni Jean à Paul. He sm has not seen Luc talk to Lea nor John to Paul 'He didn't see Luc talk to Lea nor John to Paul'

However, the infinitive can also be negated as in (48), in a pragmatic context justifying the perception of the non-occurrence of an event (e.g., in a crime case where a conversation between Jim and Lea is crucial):

(48) Le témoin a vu [Jim ne pas parler à Léa].

[DP [TP [NegP [vP]]]]]

When such full infinitive clauses are conjoined, then, the prediction is that $n i$ is not licensed, since $n i$ is inside the first clause, and the sentence is out, which is borne out, cf. (49), the counterpart to (47) with an embedded negation:

(49) ${ }^{\star} L e$ témoin a vu [Jim ne pas parler à Léa] ni [Jean (ne pas) l'embrasser]. [DP TP NegP vP] ni [DP NegP1 TP NegP vP]

Our analysis predicts that in a gapped version of the second conjunct, the $n i$ conjoining the vPs are c-commanded by the negation, yielding a grammatical sentence $^{16}$ :

(50) Il a vu Jim ne pas parler à Léa ni Jean à Paul.

[DP TP NegP [vP ni vP]]

Some speakers find embedded negations in ECM rather marked, but they find (48) and (50), or (51) and (52) equally good, which confirms our proposal's predictions.

16 Whether the negation in infinitive structures stands in NegP or is adjoined to vP is irrelevant here, since it would still scope over the conjuncts. 
(51) [in the context of an acrobatics performance:]

J'ai senti Léo ne pas prendre appui sur mon genou.

I felt Leo sm not lean on my knee

'I felt that Leo hadn't leant on my knee'

(52) J'ai senti Léo ne pas prendre appui sur mon genou ni Tom

I felt Leo sm not lean on my knee nor Tom

sur mon épaule, et j'ai su qu'on allait tomber.

on my shoulder and I have known that we went fall

'I felt that Leo hadn't leant on my knee nor Tom on my shoulder, and

I knew we were going to fall'

A low coordination analysis of ni-gapped sentences then straightforwardly accounts for the ability of $n i$ to be licensed in all these contexts, while being consistent with the usual patterns of conjunction by ni and the ability for quantifiers to bind into the gapped conjunct. In the next section, I turn to gapped conjuncts introduced by double ni, and show that they argue for a non-homogeneous analysis of gapping.

\section{Simple and double ni}

Clausal constituents can also be conjoined by the double conjunction ni... ni 'neither nor'. Though both clausal coordination and gapping are rather unusual with ni... ni, and have a very literary flavor, they are attested, as (53) and (54) show respectively:

(53) Ni l'usufruitier ne peut disposer du fonds, ni celui Nor the usufructuary sm can have of.the funds nor the.one qui a la nue propriété ne peut disposer des fruits. who has the ownership sm can have of.the fruits 'Neither can the usufructurary have the property nor can the owner have the income' (Jean Jaurès, Études socialistes, 1901, p.165)

(54) $\mathrm{Ni}$ un français ne peut prononcer un mot anglais, nor a French sм can pronounce a word English ni un anglais ne peut prononcer un mot français. nor a English sm can pronounce a word French 
'Neither can the French pronounce a single English word, nor can the English pronounce a single French word.'

(R. De Gourmont, Esthétique de la langue française, 1899, p.84)

Abeillé et al. (2011) put forward a crucial argument against Johnson's analysis of gapping: in French double ni constructions, one ni immediately precedes each conjunct. A vP-coordination analysis then wrongly predicts the ungrammatical (55b) instead of the grammatical (55c) to be the gapped equivalent of (55a), a shortened version of (54):

(55) a. Ni Paul ne connaît un mot d'anglais ni Jim

Nor Paul SM knows one word of English nor Jim

ne connaît un mot de français.

sM knows one word of French

'Neither does Paul know a single English word, nor does Jim know a single French word'

b. *Paul ne connaît ni un mot d'anglais ni Jim

Paul SM knows nor one word of English nor Jim

un mot de français.

one word of French

'Paul knows neither a single English word, nor does Jim know a single French word'

c. Ni Paul ne connaît un mot d'anglais ni Jim

Nor Paul sm knows one word of English nor Jim

un mot de français.

one word of French

'Neither does Paul know a single word of English nor Jim a single word of French'

However, this argument holds only if all instances of gapping share the same structure, a view that has been argued against for other languages (see for instance Repp 2009 for German, and Centeno 2011 for Spanish). Simple and double ni indeed exhibit differences that bear on they behavior as regards gapping. First, as noted by De Swart (2001) and Mouret (2007), unlike simple ni, double ni is a negative expression: it turns the constituents it conjoins into a global negative item, which triggers a dependency-ne on the verb of the clause it pertains to - the main clause in (56a), where it negates the CP object, the embedded TP it negates in (56b). ${ }^{17}$

17 Mouret (2007) also clearly shows that it enters Negative Concord chains with the locality properties of negative items, not that of NPIs. 
(56) a. Il n' a su ni que Jim était à Rome ni que Léa He sm has known nor that Jim was in Rome nor that Lea était à Paris. was in Paris

'He knew neither that Jim was in Rome neither that Lea was in Paris'

b. Il a dit que ni Jim n' était à Rome ni Léa n' He has said that nor Jim SM was in Rome nor Lea SM était à Paris. was in Paris

'He said that neither was Jim in Rome nor was Lea in Paris'

This entails an important difference between ne... pas... ni and ni... ni: double ni can conjoin TPs, as is the case in (56b) as well as in (57a), which contrasts with (39b) featuring simple ni, repeated under $(57 \mathrm{~b})^{18}$ :

a. On l'a fait sans que ni Paul ne pleure

We it.have done without that ni Paul sm weep.subj

ni Marie ne s'inquiète.

nor Mary SM REFL.worry.suBJ

'We did it without neither Paul weeping nor Mary getting worried'

b. ${ }^{\star}$ On l'a fait sans que Paul pleure ni Marie

We it.have done without that Paul weep.subj nor Mary

s'inquiète.

REFL.wOrry.SUBJ

'We did it without Paul weeping nor Mary getting worried'

Likewise, (58a) contrats with (41b) repeated here as (58b): gapped clauses with double ni don't admit binding from the first conjunct's subject into the second one, as (58a) shows:

(58) a. *Ici, ni chaque enfant n' aura (jamais) un violoncelle Here, nor each kid SM have.Fut (never) a cello ni ses parents les moyens de lui en louer un. nor his parents the money of to.him PART rent one 'Here, neither will each child (ever) own a cello, nor his parents enough money to rent one for him'

18 One reviewer does not find a clear difference between (57a) and (57b), but seems to equally dislike all clausal uses of ni... ni, including the attested ones. While my informants, on the whole, tend to find clausal (ni)... ni kind of akward, they unanimously find the starred examples bad or very strongly degraded. 
b. Ici, jamais chaque enfant n' aura un violoncelle ni Here, never each kid sm have.Fut a cello nor ses parents les moyens de lui en louer un. his parents the money of to.him PART rent one 'Here, never will each child own a cello, nor his parents enough money to rent one for him'

In this respect, French gapped clauses with double ni pattern with Spanish gapped clauses with simple or double ni: Centeno (2011: 97-99) argues that in Spanish, gapping in NEG-nor clauses must involve CP-coordination; she analyzes Spanish $n i$ as 'and NEG' and grounds her proposal on the impossibility of cross conjunct binding in such contexts, as (59a) and (59b), her (221) and (222), show. If she is right, then the same conclusion must be drawn for French gapped clauses with double ni: (59c), the French equivalent of (59b) is ungrammatical, too.

(59) a. ${ }^{\star}$ Cada chico no no ha tocado la guitarra ni su su $_{i}$ padre [] Each boy not has played the guitar nor his father [] el trombón.

the trombone

'Each boy has not played the guitar nor his father has played the trombone.'

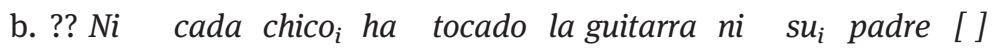
Neither each boy has played the guitar nor his father [] el trombón.

the trombone

'Neither each boy has played the guitar nor his father has played the trombone.'

c. ${ }^{*} \mathrm{Ni}$ chaque enfant $n$ ' a joué de la guitare ni son père Nor each boy SM has played of the guitar nor his father $d u$ trombone.

of the trombone

'Neither each boy has played the guitar nor has his father played the trombone.'

d. Chaque enfant n' a pas joué de la guitare ni son père Each boy SM has not played of the guitar nor his father $d u$ trombone.

of the trombone

'Each boy has not played the guitar nor his father the trombone.' 
Conversely, (59d), the equivalent of (59a), is good, which confirms that French gapped clauses with simple ni, relying on vP-coordination, differ both from French gapped clauses with double ni and from Spanish gapped clauses involving both kinds of ni. Note that Centeno analyzes both Spanish ni... ni and NEG... ni as and NEG, in parallel to Wurmbrand's (2008) analysis of English nor and German noch. For French, Mouret (2007) independantly argues that French double ni involves (two instances of) and NEG, and thus differs from the NPI ni that corresponds to or. The status of the connectors then cross-linguistically pattern with the structure of gapped structures. As for French ni... ni gapped clauses, they can proceed either from CP/TP-coordination plus deletion (cf. Centeno [2011]), or from the coordination of a fragment (cf. Abeillé and Mouret [2010]).

The wrong predictions made by a vP-coordination analysis for French ni... ni-gapped clauses do not undermine our analysis of ni-gapped clauses: it only shows that in French, like in other languages, gapping can proceed from different mechanisms.

\section{Conclusion}

In French, the need for an overt item in scopal position to license simple ni adds a syntactic argument to approaches arguing for the necessity of a low-coordination structure in gapping: the properties of gapped constituents conjoined by simple ni, whether they belong to a tensed or untensed clause, can indeed be accounted for under such an analysis, while TP-deletion approaches fail to predict the data, and fragment approaches require further investigation on how non-canonical constructions accommodate these contraints. The contrasts between gapped clauses involving simple and double ni also suggest that while the former stem from low coordination, the latter rely on clause level coordination: they comfort expanding claims in the literature that gapping is not a uniform phenomenon, and that in each language different instances of gapping may coexist, and advocate for a finer-grained investigation of gapping.

\section{References}

Abeillé, Anne. 2005. Les syntagmes conjoints et leurs fonctions syntaxiques. Langages 160. 42-66.

Abeillé, Anne, \& François Mouret. 2010. Quelques contraintes sur les coordinations elliptiques en français. Revue de sémantique et de pragmatique 24. 177-207. 
Abeillé, Anne, Gabriella Bîlbîie \& François Mouret. 2011. A Romance perspective on gapping constructions. In Hans Boas \& Francisco Gonzálvez-García (eds.), Romance in construction grammar, 227-265. Amsterdam: John Benjamins.

Benincà, Paola \& Cecilia Poletto.2004. Topic, focus and V2: Defining the CP sublayers. In Luigi Rizzi (ed.), The structure of $C P$ and IP: The cartography of syntactic structures, vol. 2, 52-75. New York: Oxford University Press.

Borsley, Robert. 2005. Against ConjP. Lingua 115. 461-482.

Centeno, Naiara. 2011. Gapping and determiner sharing in Spanish. Vitoria-Gasteiz: University of the Basque Country PhD Dissertation.

Chaves, Rui P. 2005. A linearization-based approach to gapping. In G. Jaeger, P.Monachesi, G. Penn \& S.Wintner (eds.), FG-MOL 2005: The 10th conference on formal grammar and the 9th Meeting on mathematics of language, 207-220. Edinburgh: University of Edinburgh.

Coppock, Elizabeth. 2001. Gapping: In defense of deletion. In Mary Andronis, Christopher Ball, Heidi Elston \& Sylvain Neuvel (eds.), Proceedings of Chicago linguistic society 37, 133-148. Chicago: Chicago Linguistic Society.

Culicover, Peter \& Ray Jackendoff. 2005. Simpler syntax. Oxford: Oxford University Press.

Dalrymple, Mary, Suart M. Shieber \& Fernando C. M. Pereira. 1991. Ellipsis and higher order unification. Linguistics and Philosophy 14(4). 399-452.

De Swart, Henriëtte. 2001. Négation et coordination: La conjonction ni. In Reineke BokBennema, Bob de Jonge, Brigitte Kampers-Manhe \& Arie Molendijk (eds.), Adverbial modification, 109-124. Amsterdam: Rodopi.

Gengel, Kirsten. 2009. Phases and ellipsis. Linguistic Analysis 35. 21-42.

Godard, Danièle. 2004. French negative dependency. In Francis Corblin \& Henriëtte de Swart (eds.), Handbook of French semantics, 351-389. Stanford, CA: CSLI Publications.

Hankamer, Jorge \& Marcela A. Depiante. 2005. Non-constituent ellipsis. Workshop on Identity in Ellipsis. University of California, Berkeley.

Hartmann, Katharina. 2000. Right node raising and gapping. Interface conditions on prosodic deletion. Philadelphia: John Benjamins.

Hoeksema, Jack. 2000. Negative polarity items: Triggering, scope and c-command. In Laurence R. Horn \& Yasuhiko Kato (eds.), Negation and polarity. Semantic and syntactic perspectives, 115-146. Oxford: Oxford University Press.

Huddleston, Rodney \& Geoffrey K. Pullum. 2002. The Cambridge Grammar of the English Language. Cambridge: Cambridge University Press.

Johnson, Kyle. 1996/2003. In search of the English middle field. Manuscript. Amherst: University of Massachusetts at Amherst.

Johnson, Kyle. 2009. Gapping is not (VP-) ellipsis. Linguistic Inquiry 40(2). 289-328.

Kayne, Richard S. 1994. The antisymmetry of syntax. Cambridge, MA: MIT Press.

Kim, Jeong-Seok. 2006. Gapping: Movement or deletion? Studies in Generative Grammar 16(4). 595-614.

Laka, I. (1990). Negation in Syntax: On the Nature of Functional Categories and Projections. Boston: Massachusetts Institute of Technology Doctoral Dissertation.

Merchant, Jason. 2004. Fragments and ellipsis. Linguistics and Philosophy 27. 661-738.

Merchant, Jason. 2008. Variable island repair under ellipsis. In Kyle Johnson (ed.), Topics in ellipsis, 132-153. Cambridge: Cambridge University Press.

Mouret, François. 2007. Syntaxe et sémantique des constructions en NI. Faits de langues 28. 196-205.

Munn, Alan. 1992. A null operator analysis of ATB gaps. The Linguistic Review 9. 1-26. 
Pollock, Jean-Yves. 1989. Verb movement, universal grammar, and the structure of IP. Linguistic Inquiry 20(3). 365-424.

Repp, Sophie. 2009. Negation in gapping. Oxford: Oxford University Press.

Sag, Ivan. 1976. Deletion and logical form. Boston: Massachusetts Institute of Technology Doctoral Dissertation.

Toosarvandani, Maziar. 2013. Gapping is low coordination (plus VP-ellipsis): A reply to Johnson. Ms, http://people.ucsc.edu/ mtoosarv/papers/gapping-vp-ellipsis.pdf. (accessed 23 June 2014).

Wurmbrand, Susi. 2008. Nor: Neither disjunction nor paradox. Linguistic Inquiry 39(3). 511-522.

Zanuttini, Raffaella. 2001. Sentential negation. In Mark Baltin \& Chris Collins (eds.), The handbook of contemporary syntactic theory, 511-535. Malden: Blackwell.

Zeijlstra, Hedde. 2010. On French negation. In I. Kwon, H. Pritchett and J. Spence (eds.), Proceedings of the 35th annual meeting of the Berkeley linguistics society, 447-458. Berkeley, CA: Berkeley Linguistic Society. 